\title{
IMPACT OF CORPORATE SOCIAL RESPONSIBILITY ON THE COMPANY'S REPUTATION IN MANUFACTURING COMPANIES IN THE BASIC INDUSTRY AND CHEMICALS SECTOR, CEMENT SUB-SECTOR LISTED ON THE IDX 2012-2017
}

\author{
Syamsul Riyadi, Ilham Safar \\ Faculty of Economics and Social Sciences, Universitas Fajar Makassar \\ Email: syamsulriyadi@gmail.com
}

\begin{abstract}
This study uses secondary data sources via the Indonesia Stock Exchange website as a sample of manufacturing companies in the basic industrial sector and chemical sector of the cement sub-sector from 2012 to 2017. This research data was analyzed using the partial least squares (PLS) method. program.The results showed that: (1) corporate social responsibility (X1) has a significant effect on the reputation of the company (X2). (2) Corporate social responsibility (X1) has a significant effect on the value of the company $(Y)$. (3) the reputation of the company $(X 2)$ has a significant effect on the value of the company $(Y)$. (4) Corporate social responsibility (X1) has a significant effect on the value of the company $(Y)$ mediated by the reputation of the company (X2).
\end{abstract}

Keywords : Corporate Social Responsibility, Corporate Reputation, Corporate Value and Tobins' $Q$

DOI: http://dx.doi.org/10.29040/jap.v22i1.2363

\section{INTRODUCTION}

The main goal of companies that have gone public is to maximize the value of the company by increasing the prosperity of shareholders. Firm value can provide maximum prosperity to shareholders if the stock price rises. The higher the share price of a company, the higher the prosperity of shareholders. Enterprise Value (EV), also known as Enterprise Value, is an important concept for investors because it is an indicator that allows the market to assess the business as a whole. Firm value is the price a potential buyer is willing to pay if the business is sold. The firm value is a reflection of the increase in equity of the business along with the debt of the business. Several factors influence the value of the company, namely: financing decisions, dividend policy, investment decisions, capital structure, company growth, company size, some of these factors have an inconsistent relationship and influence on the value of the business. Firm value is the value of expected future earnings which is recalculated at the correct interest rate. (Kusumadilaga, 2010).
The rapid development of the Indonesian Stock Exchange (IDX) today cannot be separated from the role of investors who trade on the IDX. The Indonesian capital market is classified as a growing capital market and has an impact on the Indonesian economy. IDX is one of the benchmark capital market exchanges in Indonesia with 544 members, of which 144 are in the manufacturing industry (www.sahamok.com). Manufacturing companies in the conduct of alternative sources of finance to meet business needs Therefore, the company must be able to increase the maximum value of the company in order to attract investors to invest.

However, the development of a business cannot only be assessed on the value of the business. As the business grows, the level of social inequalities and environmental damage will increase due to the activities of the business. Manufacturing companies are classified as environmental impact companies compared to service companies or trading companies. Data from Merakati (2016) in Pratama (2017) in 2014, 
there were 14 manufacturing companies or $12.71 \%$ of companies did not disclose environmental or community empowerment which was divided into 3 sectors. In various industrial sectors there were 7 companies or $6.08 \%$, followed by the consumer goods industry sector with 4 companies or $3.47 \%$ and the basic chemical industry sector with 3 companies or $2.60 \%$.

Manufacturing companies in basic industrial and chemical sectors tend to have the potential to harm the environment, especially during the production process where the industrial sector releases a lot of waste and certain substances that cause pollution ranging from pollution of water or air which causes air. smell bad. disrupt breathing and can damage the ozone layer which endangers the survival of all land creatures in general and the surrounding community in particular.

\section{Formulation of the Problem}

Based on the discussion of the background above, the formulation of the problem raised by the author is whether corporate social responsibility affects the reputation of the company?

\section{Literature Review}

\section{(1) Signaling Theory}

Is an explanation of the asymmetry of information. The appearance of information asymmetry is due to the fact that management has more information about the prospects of the company. To avoid information asymmetry, companies must provide information as a signal to investors. Information asymmetry should be minimized, so that SOEs can transparently report the state of the business to investors. Investors always need symmetrical information as a follow-up to invest in a business.

According to Brigham and Houston (2012: 36 ), a signal is an action taken by a company to guide investors on how management views the company's prospects. This signal comes in the form of information about what management has done to achieve the owner's wishes. The information disseminated by the company is important because it affects the investment decisions of parties outside the company. This information is important for investors and businessmen because it essentially provides information, notes or descriptions, both on the past, present and future conditions of the survival of the company and on how they affect the businesscompany.

\section{(2) Reputation}

Reputation is a major issue for every business, so it needs the same attention as risks related to operational, strategic and financial matters. A good reputation is an asset for the company on the contrary, a bad reputation is a burden for the company. As a strategic business asset, reputation plays a role in gaining competitive advantage and improving business performance (Hall et al. In Wang, 2006). If reputation is seen as a burden on the business, then the business goal is to reduce the impact that reputation can have.

Fombrun (2005) argues that company reputation is the point of view or perception of the company by people both inside and outside the company. Business observers are clients or clients of the business, namely retailers, in addition to others, such as shareholders, communities, banks and working partners.

The importance of maintaining a positive corporate reputation, representative of corporate performance and from a social perspective, has been the goal of business leaders and boards of directors over the past year. decade. Failure to recognize the importance of reputation will be the worst mistake a business can make. Companies should consider reputation to be a useful tool for measuring the overall performance of the company in the industry and the market, even reputation is the only way to measure the character of a company (Dolphin, 2004).

Company reputation can be seen from different points of view so that it has a number of different definitions of each other. The measure of the reputation of the company which is adjusted to the conditions of the Indonesian market so that it can construct the variables that form the reputation of the company, which consists of corporate governance and accounting measures. These two measurement variables are considered sufficiently representative of how the implementation mechanism of corporate governance in Indonesia is because these three measurement variables are part of the OECD Principles of Corporate Governance, which are internationally recognized for their validity. 


\section{a) Measurement of Corporate Governance}

Measure of corporate governance, namely shareholder rights, disclosure and governance practices. These three measurement variables are considered sufficient to represent the implementation mechanism of corporate governance in Indonesia because these three measurement variables are part of the OECD principles of corporate governance which are internationally recognized as valid. . Using secondary data in the form of corporate financial reports, the researcher tries to see the proxies used from each of these measurement variables such as the proportion of total returns on shareholders, the proportion of shareholding by auditors and the directors, as well as the composition of the independent auditors and the existence of the audit committee as determined by the IDX.

\section{b) AccountingMeasurement}

Financial ratios are closely linked to changes in stock prices. From an investor's perspective, financial ratios can be used to find stock purchases, lend funds, or to see a company's potential in the future. In this study, only three ratios often used by investors to measure the financial / accounting performance of the company were retained, namely the liquidity ratio, the leverage ratio and the profitability ratio, so that in this study, the accounting measures were measured through three financial measures. variables, namely the current ratio which represents the liquidity ratio, the debt / equity ratio which indicates the solvency ratio (leverage ratio) and the return on equity which represents the profitability ratio.

\section{1) Debt to Equity Ratio (DER)}

It is a ratio used to measure the ability of a company to repay its long-term obligations, this ratio is formulated as a division between the debt or the long-term liabilities of the company (equity). The higher the DER value, which reflects the relatively high risk of the business, so investors try to avoid a high DER value.

\section{2) Return on Equity (ROE)}

The ROE shows that the earning power of the holder's investment value is a complete approximation of the performance of the company because it indicates the manager's ability to manage the funds invested by the shareholders of the company to obtain returns. . ROE is the ratio of net income (NI) for one year to equity $€$ at the end of a certain year. The higher the value of ROE, the more efficiently the company uses its own capital to generate profits.

\section{3) Current Ratio}

It is a ratio that measures the ability of the company to repay its short-term obligations by liquidating its current assets, that is to say by transforming assets into cash. The higher the current ratio held shows the size of the company's ability to meet its operational needs, in particular the working capital which is very important to maintain the performance of the company which in turn affects the price of actions.

\section{(3) Corporate Social Responsibility}

According to the World Business Council for Sustainable Development (WBCSD), corporate social responsibility (CSR) is defined as a commitment of companies to contribute to sustainable economic development, in collaboration with employees and their representatives, their families, the community local. and the general public to improve the quality of life in a way that benefits both its own business and development.

CSR or corporate social responsibility can also be defined as actions that are part of the continuation of social actions, outside the interests of the company and those required by law (McWilliams and Siegel, 2001 in Agustine, 2014). CSR is a concept development proposed by John Elkington in 1997, namely "The Triple Bottom Line". In this concept it is stated that in order for a company to maintain its sustainability, it is necessary to pay attention to $3 \mathrm{P}$, which is not only profit, but also able to contribute to society (people) and participate actively preserving the environment (planet).

Hendriksen and Widjajant (1991: 203) in Agustine (2014) define disclosure as presenting a certain amount of information necessary for an optimal and efficient functioning of the capital market. Some disclosures are mandatory and others voluntary. The concept of CSR reporting was initiated as part of the Global Reporting Initiative (GRI). In the GRI guidelines, it is stated that companies should explain the impact 
of their activities on economic, environmental and social aspects in the standard information section. The three dimensions are then developed into 6 dimensions, namely economic, social, environmental, labor practices, human rights, community and product responsibility, in which there is an explanation of a number of 79 elements.

\section{Conceptual Framework}

This study examines the effect of corporate social responsibility on company value, the influence of corporate social responsibility on company reputation, the influence of company reputation on value of the company and how the reputation of the company mediates the relationship between corporate social responsibility and the value of the company in the core manufacturing sector. companies and the chemical sector in the cement sub-sector. listed on the Indonesian Stock Exchange for the period 2012-2017. The indicators used to measure corporate social responsibility refer to the GRI (Global Reporting Initiatives) indicator which focuses on several disclosure components, namely the economic dimensions, the environmental dimensions, the social dimensions, the rights of the people, local communities and product responsibility as the basis for sustainable development reporting. measured using dummy variables, namely:

Score 0: if the company does not disclose the element of the questionnaire.

Score 1: if the company discloses an element of the questionnaire.

At the same time, for the reputation of the company, the variables forming the reputation of the company are divided into two measurement variables, namely the measure of corporate governance and the measure of the accounting measure.

The measure of company value can be seen in terms of analyzing financial statements in the form of financial ratios and in terms of changes in stock prices. In this study, the value of the company is measured using Tobin's Q which is calculated with the following formula:

$$
\text { Tobins' } q=\frac{(M V E+D E B T)}{\mathrm{TA}}
$$

The conceptual framework of this study is as follows:

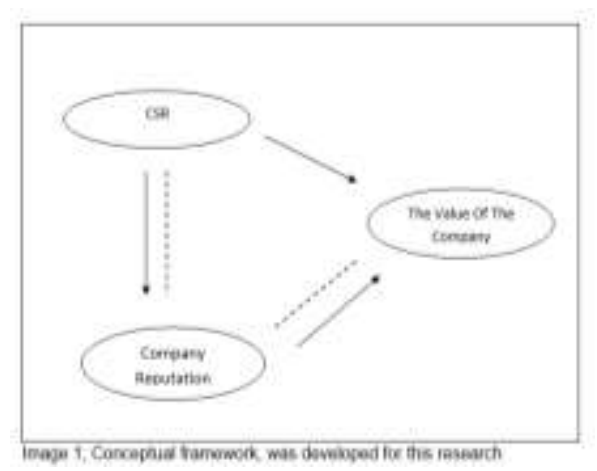

Figure 1. Conceptual Framework

\section{RESEARCH METHOD Research Design}

Based on the formulation of the problem and its objectives, this study uses descriptive quantitative research that provides a more detailed description of a symptom from existing data, presents data, analyzes interpretations.

\section{Place and time of the search}

This research was carried out at company level, namely all manufacturing companies in the cement sub-sector of the basic industrial sector and chemicals. Using primary data from 2012 to 2017. Research timing was 2021.

\section{Data types and sources}

The type of data used in this research is quantitative in the form of financial statements of manufacturing companies listed on the IDX from 2012 to 2017 which are the latest data. The type of data used in this study is panel data, that is, data that is cross-collected and selectively collected including multiple companies and then followed by a six-year time series (2012-2017).

The data sources used in this study are secondary data obtained through the Indonesia Stock Exchange website, www.idx.co.id. The companies listed on the Indonesian Stock Exchange have a total of 544 members, of which 144 are manufacturing enterprises and manufacturing enterprises themselves composed of 3 sectors, namely basic industry and chemical sector, various industries and the sector of the consumer goods industry. The research sample to be examined in this study, namely manufacturing companies located in basic industry and chemical sector, is presented in the following table: 


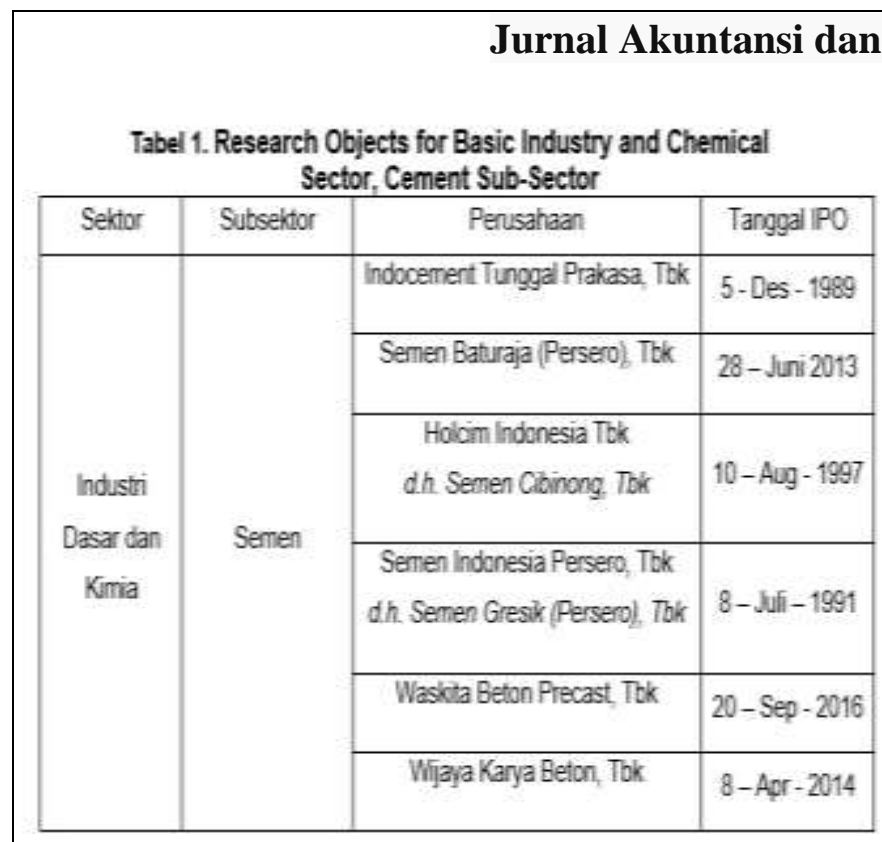

Source : www.idx.co.id (2021)

\section{Data collection technique}

The data collection method used in this study is to use the documentation method, i.e. the annual report method and the literature study which is carried out by studying the required documents or data, followed by registration and review. calculation and tracing of financial statements of companies in Indonesia. Stock Exchange website for data on company value from 2012 to 2017.

\section{Data Analysis Techniques}

This study used data analysis with the partial least squares (PLS) approach. The PLS approach is based on a shift from the analysis of the measure from the estimation of the parameters of the research model to the relevant predictive measure, so that the objective of the measure shifts from the estimation of only the estimation of the importance of the parameters (structural path and loading factor). to the validity of the prediction. The basis used is the resampling developed by Geisser \& Stone in Solimun (2010: 180).

The steps of the SEM-PLS test are described as follows:

1. Design of the structural model

2. Design of the measurement model

3. Construction of the path diagram

4. Converting the flowchart to a system of equations

5. Estimation of the model

\section{Population dan Sample Population}

The population used in this study is made up of manufacturing companies in the basic industry and chemicals sector, cement sub-sector, which have gone public and listed on the Indonesian Stock Exchange. The manufacturing companies that were included in the list are getting more public attention.

\section{Sample}

The research sample was taken from a population that existed between 2012 and 2017 . This period was chosen because fairly recent data can be obtained. With data by period, it is hoped that he will perform well in explaining the company's CSR activities.

\section{RESULT AND DISCUSSION \\ 3.1. Research Results}

1. Research construct measurement model (Outer model)

This study includes 3 (three) variables, namely: corporate social responsibility (X1), company reputation (X2) and company value (Y) Data were processed using SEM-PLS and refer to discriminant validity, convergent validity, and composite reliability. The results of the overall search pattern after being processed using SEMPLS can be seen as in Figure 2.

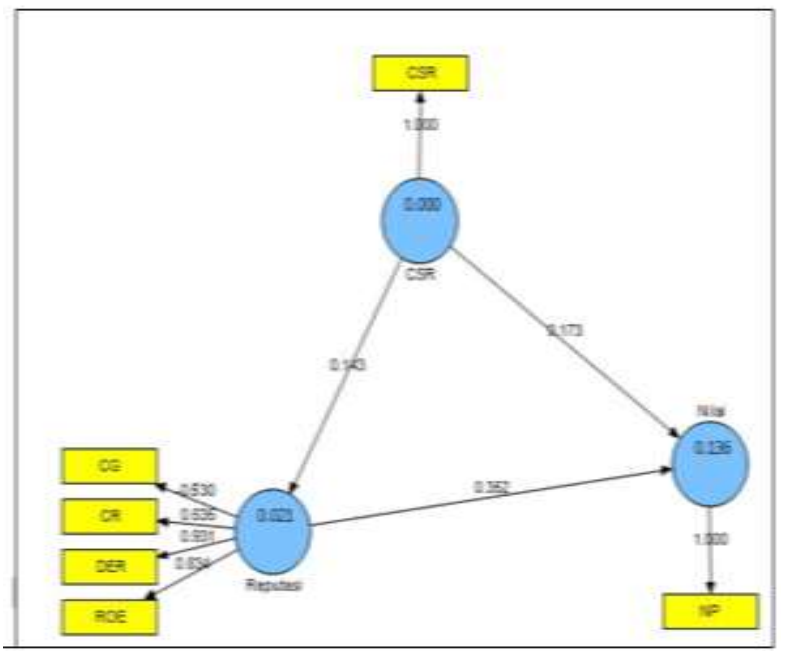

Figure 2. Search Results Model

Source : Results of data processing with PLS software, 2021

\section{a. Corvergent Validity}

The measurement model of the research variable is evaluated by analyzing the convergent validity of each indicator, which is tested on the PLS seen from the size of the external load of each indicator on its latent variable. External load values greater than 0.70 are strongly 
recommended, but load factor values of 0.50 to 0.60 can still be tolerated with a statistic value greater than 1.96 or a $p$ value $<0,05$ (Ghozali, 2012). The external load of an indicator with the highest value is the strongest or most important metric to reflect the latent variable in question. The external load value interprets the contribution of each indicator used to its latent variable

The evaluation of the external model or the measurement model can be seen from the external load value of each variable indicator. Figure 4 depicts the value of the load factor for the search variables. The value of the load factor on the corporate social responsibility (CSR) indicator is 1000 , the corporate governance $(\mathrm{CR})$ is 0.530 , the current ratio (CR) is 0.635 , the debt / fund ratio Equity (DER) is 0.931, Return on Equity (ROE) is 0.834 , and Firm Value (NP) is 1000, which means the factor loading value is above the critical limit of 0,5 . Since the external load value of each indicator is greater than 0.500 , all factors will be included in the model. Thus, the three variables of this study could be well established or explained by their respective indicators or can be said to be valid convergent on these indicators.

\section{b. Discriminant Validity}

The discriminant validity assessment in this study used the cross-loading value, the extracted mean variance (AVE), and Cronbach's alpha value. Discriminant validity tests can be explained as follows:

\section{1) Cross Loading}

Table 2. Cross Loading Calculation Results

\begin{tabular}{|c|c|c|c|}
\hline Indikator & CSR & Nilai & Reputasi \\
\hline CSR & 1.000000 & 0.122396 & 0.143388 \\
\hline CG & 0.023964 & 0.019726 & 0.530235 \\
\hline CR & 0.072072 & 0.231508 & 0.635108 \\
\hline DER & 0.239738 & 0.205946 & 0.930694 \\
\hline ROE & 0.039292 & 0.339702 & 0.834088 \\
\hline NP & 0.122399 & 1.000000 & 0.326807 \\
\hline
\end{tabular}

Source : PLS processed results, 2021
Based on Table 2, it can be seen that the cross-loading value for the indicators of this search variable is greater than the cross-loading value of the indicators for other latent variables. This shows that the indicators used for each variable are able to explain each variable better than the other variables, so that the research instrument is said to be valid in a discriminant manner.

2) Average Variance Extracted (AVE)

Table 3. Average Variance Extracted (AVE) Value

\begin{tabular}{|c|c|c|}
\hline Variabel & AVE & Keterangan \\
\hline $\begin{array}{l}\text { Corporate Social } \\
\text { Responsibility (CSR) }\end{array}$ & 1.000000 & \multirow{3}{*}{$\begin{array}{l}\text { Indikator dikatakan valid } \\
\text { secara discriminant, } \\
\text { jika nilai AVE-nya }>0.5\end{array}$} \\
\hline Nilai Perusahaan (Nilai) & 1.000000 & \\
\hline $\begin{array}{l}\text { Reputasi Perusahaan } \\
\text { (Reputasi) }\end{array}$ & 0.591542 & \\
\hline
\end{tabular}

Source : PLS processed, 2021

The results of the tests in Table 3 show that the mean value of the extracted variance (AVE) of all the variables is greater than the tolerance limit of 0.50 . This means that the variables in this study have good discriminant validity and can be considered to have satisfied the criteria for discriminant validity.

3) Cronbach Alpha

Table 4. The value of composite reliability and cronbach alpha research variables

\begin{tabular}{|l|c|c|}
\hline \multicolumn{1}{|c|}{ Variabel } & Cronbachs Alpha & Keterangan \\
\hline $\begin{array}{l}\text { Corporate Social } \\
\text { Responsibility } \\
\text { (CSR) }\end{array}$ & 1.000000 & $\begin{array}{c}\text { Indikator } \\
\text { dikatakan baik } \\
\text { jika nilai } \\
\text { composite } \\
\text { reliability dan } \\
\text { cronbach } \\
\text { alpha }>0.6\end{array}$ \\
\hline $\begin{array}{l}\text { Nilai Perusahaan } \\
\text { (Nilai) }\end{array}$ & 1.000000 & \\
\hline $\begin{array}{l}\text { Reputasi } \\
\text { Perusahaan } \\
\text { (Reputasi) }\end{array}$ & 0.632957 & \\
\hline
\end{tabular}

Source : PLS processed, 2021

Based on Table 4, it can be seen that the Cronbach's alpha value in the search variable is greater than 0.600 and the latent variable can be said to have high reliability. Thus, all the instruments used in this study met the criteria or are feasible to be used in the measurement of all the variables studied, as they have good validity and high reliability or reliability.

From the results of the assessment of convergent validity and discriminant validity for 
indicators or variables, it can be concluded that indicators as a measure of latent variables, each of which is a valid and reliable measure.

\section{Goodness of Fit (Inner Model) Testing}

The test of the structural model (internal model) is performed after the estimated model satisfies the criteria of convergent validity and discriminant validity. The test consists of examining the relationship between the variables studied by examining the estimated results of the coefficient of the path parameter and its level of significance (Ghozali, 2008). The estimation results were obtained by the bootstrap procedure and evaluated using the $t$ statistical test.

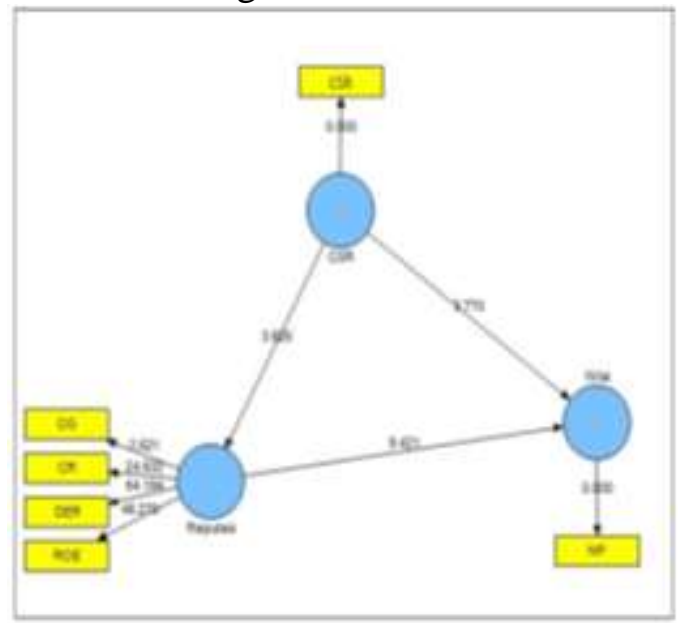

Figure 3. Bootsrapping Research Model

Source : Resault of data processing with PLS software, 2021

In this study, the structural model is assessed by paying attention to R-squared (R2) and Q2 (predictive relevance model). $\mathrm{R} 2$ is the coefficient of determination, while Q2 measures the extent to which the observed value is generated by an R2-based model of all endogenous variables. The value of $\mathrm{Q} 2$ is between 0 and $1(0<\mathrm{Q} 2<1)$, the closer the model is to the value 1 , the better the model. Here are the results of the calculation of the coefficient of determination (R2) which are presented in Table 5.

Table 5. Value goodness of fit (R-Square)

\begin{tabular}{|c|c|c|}
\hline Pengaruh & Terhadap & R Square \\
\hline $\begin{array}{r}\text { Corporate Social Responsibility } \\
\text { (CSR) }\end{array}$ & $\begin{array}{c}\text { Reputasi Perusahaan } \\
\text { (Reputasi) }\end{array}$ & 0.020560 \\
\hline $\begin{aligned} \text { Corporate Social Responsibility } \\
\text { (CSR) }\end{aligned}$ & Nilai Perusahaan (Nilai) & 0.136052 \\
\hline Reputasi Perusahaan (Reputasi) & & \\
\hline
\end{tabular}

Source : PLS processed results R Square Table, 2021

Table 5 above shows that the coefficient of determination (R-squared) obtained from the CSR model on company reputation is 0.021 , so it can be argued that the company reputation variable can be explained by the CSR variable of $2.1 \%$ and the rest is influenced by other variables outside of research. Then the coefficient of determination (R-squared) obtained from the CSR model and the reputation of the company on marketing performance is 0.136 so that it can be explained that the variable value of the company can be explained by the CSR variable and the company's reputation of $13.6 \%$ and is influenced by other external variables. research.

Then, from the output of the PLS model, the structural model and the hypothesis test are performed by examining the estimated value of the path coefficient and the value of the critical point ( $t$ statistic) on the direct effect and the statistical value sobel on the significant indirect effect if the value is greater than 1.96 (> 1.96), which can be seen in Table 6 .

Table 6. Results of path coefficients and hypothesis testing of direct and indirect effects

\begin{tabular}{|c|c|c|c|c|c|c|c|c|}
\hline \multirow{2}{*}{ Mlpotenin } & \multicolumn{3}{|c|}{ Varacel } & \multirow{2}{*}{$\begin{array}{l}\text { Dinet } \\
\text { ENhet }\end{array}$} & \multirow{2}{*}{$\begin{array}{l}\text { nolinet } \\
\text { Elfect }\end{array}$} & \multirow{2}{*}{$\begin{array}{l}\text { Total } \\
\text { Ehtoct }\end{array}$} & \multirow{2}{*}{ 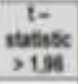 } & \multirow[b]{2}{*}{ Ket } \\
\hline & Indevenden & Mediani & Dependen & & & & & \\
\hline 1 & CSR & - & Resutan & 0140 & - & 010 & 3025 & sig \\
\hline 2 & CSR & $=$ & $\begin{array}{c}\text { Mitai } \\
\text { Perusatan }\end{array}$ & $0 m$ & $=$ & oth & $37 \pi$ & 50 \\
\hline 3 & Reatas & . & $\begin{array}{c}\text { Nex } \\
\text { Penisatan }\end{array}$ & 152 & - & 0352 & 9421 & sig \\
\hline 4 & $\operatorname{csh}$ & 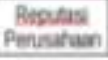 & $\begin{array}{c}\text { Nitai } \\
\text { Penuatan } \\
\end{array}$ & 010 & 0050 & 019 & 3383 & Sig \\
\hline
\end{tabular}

Source : PLS processed, 2021

\section{RESULT AND DISCUSSION}

a. Testing the first hypothesis: Corporate Social Responsibility affects the company's reputation 
The measurement of the reputation of the company in this study consists in using the disclosure of the corporate governance and the instruments of measurement of the accounting measure, in particular by using three variables namely the current ratio, the debt on the equity and return on equity. A good business reputation is an asset for the business, but otherwise a bad reputation is a burden on the business. However, based on the samples taken, the average business has a positive reputation value, which means that the reputation of the business in the cement manufacturing industry is an asset to the business.

The results of the analysis using the PLS show that CSR has a positive and significant effect on the reputation of the company with the statistical value $\mathrm{t}>\mathrm{t}$ table 1.96. This can be seen from the t-statistic value of 3.625 , which means that the CSR concept has an effect on building the reputation of the company.

The results of this study are supported by Kartikasari (2008) who asserts that social responsibility affects the reputation of the company. This means that in times of crisis, companies with a good track record of social responsibility prove to be faster to regain their reputation. Businesses can build a good reputation early on by fulfilling their social responsibility, rather than trying to rebuild a lost reputation.

\section{b. Testing the second hypothesis: Corporate Social Responsibility affects firm value}

The results of the analysis using the PLS show that CSR has a positive and significant effect on the value of the company with a statistical $t$ value> $t$ table 1.96. This can be seen from the t-statistic of 3.770, which means that the CSR construct has an effect on the firm's value construct. In other words, companies that disclose their company's activities or social programs more widely will have an impact on the rise in stock prices, which means an increase in the value of the company in the eyes of its investors. For the results of this study to accept the first hypothesis that CSR disclosure has an effect on the value of the company.

The results of this study are supported by the results of previous studies by Gunawan and Utami (2008) which indicate that corporate social responsibility has a positive effect on the value of the company, which means that CSR is a factor. that affects the high or low value of the business. The more companies disclose their social disclosure elements and the better the quality of the disclosures, the higher the value of the company.

\section{c. Testing the third hypothesis: Reputation affects firm value}

The measurement of the reputation of the company in this study consists in using the disclosure of the corporate governance and the instruments of measurement of the accounting measure, in particular by using three variables namely the current ratio, the debt on the equity and return on equity. A good business reputation is an asset for the business, but otherwise a bad reputation is a burden on the business. However, based on the samples taken, the average business has a positive reputation value, which means that the reputation of the business in the cement manufacturing industry is an asset to the business.

The results of the analysis using the PLS show that the reputation of the company has a positive and significant effect on the value of the company with the statistical value $t>t$ table 1.96 . This can be seen from the $t$ statistical value of 9,421 , which means that the reputation construct has an effect on the concept of enterprise value.

The results of this study are supported by Kartikasari (2008) who asserts that the reputation of the company has an effect on the value of the company.

d. Testing the fourth hypothesis: Corporate

Social Responsibility affects company value mediated by company reputation.

On the basis of Table 6 above, the results of the estimation of the mediating variable of the reputation of the company are obtained with a statistical value $t$ of 3.384 , which is greater than 1.96 or we can say that the statistical count $\mathrm{t}>\mathrm{t}$ table 1.96. This means that the reputation of the company is able to negotiate the effect of CSR disclosure on the value of the company, so the fourth assumption is accepted.

This is a new discovery where CSR disclosure can increase the value of the company by being publicized by an increased reputation of the company, due to the environmental and social responsibility of the company.

Streamlining high CSR disclosure reflects a high level of concern of the business, thereby increasing the reputation of the business, which in turn will affect the value of the business in the market. 


\section{CONCLUSION}

Based on the results of the data analysis by proving and testing the hypothesis of the issues raised regarding the impact of corporate social responsibility on the reputation and value of the company as measured using the GRI, where the company's reputation is a mediating variable between CSR and the value of manufacturing companies in the cement sub-sector. on the IDX for the period 2012-2017 as described in the previous chapter, the conclusions of this study are as follows:

Based on the first hypothesis test, it shows that corporate social responsibility (X1) has a significant effect on the reputation of the company (X2). This can be seen from the value of t statistical count> t table 1.96. This can be seen from the $t$ statistical value, which is 3.625 , which means that $\mathrm{X} 1$ has a significant effect on $\mathrm{X} 2$ because the $\mathrm{t}$ statistical value is greater than the table value, which is 1.96 .

Based on the second hypothesis test, it shows that corporate social responsibility (X1) has a significant effect on the value of the company (Y). This is known from the value of $t$ statistical count $>\mathrm{t}$ table 1.96. This can be seen from the statistical value $t$, namely 3.770 , which means that $\mathrm{X} 1$ has a significant effect on $\mathrm{Y}$ because the statistical value $t$ is greater than the value in the table, namely 1.96 .

Based on the third hypothesis test, it shows that the reputation of the company (X2) has a significant effect on the value of the company (Y). This is known from the value of $t$ statistical count> t table 1.96. This can be seen from the statistical value $t$, namely 9.421 , which means that X2 has a significant effect on Y because the statistical value $t$ is greater than the value in the table, namely 1.96 .

Based on the fourth hypothesis test, it shows that corporate social responsibility (X1) has a significant effect on the value of the company (Y) which is mediated by the reputation of the company (X2). This may explain that the reputation of the company is able to strengthen the CSR disclosure of the value of the company. We can see from the statistical value $t$ which is greater than the value of table $t(3.383>1.96)$, we can conclude that $\mathrm{X} 1$ has a significant effect on $\mathrm{Y}$ which is mediated by $\mathrm{X} 2$.

\section{REFERENCE}

Agustine, Ira. 2014. "Pengaruh Corporate Social Responsibility Terhadap Nilai Perusahaan, Vol. 2, No. 1, 42-47.

Dolphin, Richard R., 2004, "Corporate Reputation - A Value Creating Strategy", Corporate Governance, Vol. 4, No.3, pp. 77-92.

Eugene F. dan Joel F. Houston. 2012. Dasardasar Manajemen Keuangan. Jakarta: Salemba Empat.

Fombrun, C. J, 2005, "Building Corporate Reputation Through CSR Initiatives : Evolving Standards", Corporate Reputation Review, Vol. 8, No. 1, pp. 7.

Ghozali, Imam, Hengki Latan, 2012, "Partial Least Squares : Konsep, Teknik dan Aplikasi Menggunakan Program Smart PLS 2.0 M3, Semarang-Jawa Tengah, Badan Penerbit Universitas Dipenogoro.

Gunawan, et al. 2008, "Peranan Corporate Social Responsibility Dalam Nilai Perusahaan" Vol. 7, No. 2, pp 174185.

Kartika, Caecila Mita. 2008. Pengaruh Tanggung Jawab Sosial Dan Tata Kelola Terhadap Reputasi Dalam Rangka Peningkatan Kinerja Jamsostek. Semarang; Program Studi Magister Manajemen Universitas Diponegoro.

Kristiyanti, et al. 2019. “Analisis Pengaruh Marketing Activity Dan Working Capital Terhadap Profitabilitas Di PT. Krakatausteel Tahun 2010-2018". DOI : 10.29040/jap.v20i1.542 Jurnal Akuntansi dan Pajak, Vol. 20, No. 01. STIE AAS Surakarta.

Kusmadilaga, R. 2010. Pengaruh Corporate Social Responsibility terhadap Nilai Perusahaan dengan Profitabilitas Sebagai Variabel Moderating. 
Semarang; Fakultas Ekonomi Universitas Diponegoro.

Pratama,I Gusti Bagus Angga. 2016. Pengaruh Ukuran Perusahaan Dan Leverage Terhadap Nilai Perusahaan Dengan Profitabilitas Sebagai Variabel Mediasi. E-Jurnal Manajemen Unud.Vol.5.No. 2. ISSN: 2302-8912.

Rahman, R. (2009). Corporate Social Responsibility: Antara Teori dan Kenyataan. Jakarta: MedPress (Anggota IKAPI).

Solimun. 2010. Analisis Multivariat Pemodelan Struktural, Metode Partial Least Square-PLS. Malang: CV Citra Malang.

Wang, Yonggui, Jay A. Kandampully, Hing-Po Lo, Guicheng Shi, 2006, "The Roles of Brand Equity and Corporate Reputation in CRM : A Chinese Study", Corporate Reputation Review, Vol. 9, No 3, pp. 179-197 www.idx.co.id 